\section{References}

1. Celik S, Lestuzzi C, Cervesato E, Dequanter D, Piotti P, De Biasio M, et al. Systemic chemotherapy in combination with pericardial window has better outcomes in malignant pericardial effusions. $J$ Thorac Cardiovasc Surg. April 18, 2014 [Epub ahead of print].

2. Ruiz-Garcia J, Jiménez-Valero S, Moreno R, Galeote G, Sánchez-Recalde Á, Calvo L, et al. Percutaneous balloon pericardiotomy as the initial and definitive treatment for malignant pericardial effusion. Rev Esp Cardiol (Engl Ed). 2013;66: 357-63.

3. Imazio M, Spodick DH, Brucato A, Trinchero R Adler Y. Controversial issues in the management of pericardial diseases. Circulation. 2010;121: 916-28.

4. Seferović PM, Spodick DH, Maisch B, Maksimović R, Ristić AD, Roberts R. Pericardiology: contemporary answers to continuing challenges. Belgrade: Science; 2000:427-38.

5. Ziskind AA, Pearce AC, Lemmon CC, Burstein S, Gimple LW, Herrmann HC, et al. Percutaneous balloon pericardiotomy for the treatment of cardiac tamponade and large pericardial effusions: description of technique and report of the first 50 cases. J Am Coll Cardiol. 1993;21: $1-5$.

6. Patel N, Rafique AM, Eshaghian S, Mendoza F, Biner S, Cercek B, et al. Retrospective comparison of outcomes, diagnostic value, and complications of percutaneous prolonged drainage versus surgical pericardiotomy of pericardial effusion associated with malignancy. Am J Cardiol. 2013; 112:1235-9.

7. Tsang TS, Seward JB, Barnes ME, Bailey KR, Sinak LJ, Urban LH, et al. Outcomes of primary and secondary treatment of pericardial effusion in patients with malignancy. Mayo Clin Proc. 2000 75:248-53.

http://dx.doi.org/10.1016/ j.jtcvs.2015.04.013

\title{
Notices of Correction
}

Re: Rieder E, Kasimir M-T, Silberhumer G, Seebacher G, Wolner E, Simon P, Weigel G. Decellularization protocols of porcine heart valves differ importantly in efficiency of cell removal and susceptibility of the matrix to recellularization with human vascular cells. J Thorac Cardiovasc Surg. 2004;127:399-405.

In the full-text online version of the article, Figures 2 and 3 are switched. Readers should refer to the PDF or print version of the article, which are both correct.

Re: Seery TJ, Sinha P, Zurakowski D, Jonas RA. Femoral vein homograft for neoaortic reconstruction in the Norwood stage 1 operation: A follow-up study. J Thorac Cardiovasc Surg. 2013;146:550-6.

In the above-mentioned article, Table 1 contained errors in the "Overall" column for the rows "Late mortality," "Interstage death $(1 \rightarrow 2)$," and "Interstage death $(2 \rightarrow 3)$." The entries should be as follows: Late mortality, $14(13.1 \%)$; Interstage death $(1 \rightarrow 2), 4(3.7 \%)$; and Interstage death $(2 \rightarrow 3), 6(5.6 \%)$. The corrected table is reprinted on the next page. 